Corrigendum

\title{
Corrigendum to "Development and Evaluation of an Immuno- Capture Enzyme-Linked Immunosorbent Assay to Quantify the Mycoplasma capricolum subsp. Capripneumoniae (Mccp) Protein in Contagious Caprine Pleuropneumonia (CCPP) Vaccine"
}

\author{
Jean de Dieu Baziki $\mathbb{D}^{1,2}$ Charles Bodjo S. ${ }^{10},{ }^{1}$ Nick Nwankpa, ${ }^{1}$ Naomi Maina $\mathbb{D}^{2,3}$ \\ Ethel Chitsungo $\mathbb{D}^{1},{ }^{1}$ Cisse Rahamatou Moustapha Boukary $\mathbb{D}^{1},{ }^{1}$ Takele A. Tefera, ${ }^{4}$ \\ Rume Veronica Nwankpa ${ }^{D},{ }^{5}$ and Nduta Mwangi ${ }^{6}$ \\ ${ }^{1}$ African Union-Pan African Veterinary Vaccine Centre (AU-PANVAC), P.O. Box: 1746, Debre Zeit, Ethiopia \\ ${ }^{2}$ Pan African University Institute for Basic Sciences, Technology and Innovation (PAUSTI), JKUAT Main Campus, \\ P.O. Box: 62000-00200, Nairobi, Kenya \\ ${ }^{3}$ Jomo Kenyatta University of Agriculture and Technology (JKUAT), P.O. Box: 62000-00200, Nairobi, Kenya \\ ${ }^{4}$ National Veterinary Institute, P.O. Box: 19, Debrezeit, Ethiopia \\ ${ }^{5}$ Addis Ababa University, Department of Microbial Cellular and Molecular Biology, P.O. Box: 1176, Addis Ababa, Ethiopia \\ ${ }^{6}$ Kenya Veterinary Vaccines Production Institute (KEVEVAPI), P.O. Box: 53260-00200, Nairobi, Kenya
}

Correspondence should be addressed to Jean de Dieu Baziki; bazikij@africa-union.org and Charles Bodjo S.; bodjoc@africaunion.org

Received 17 March 2021; Accepted 17 March 2021; Published 28 March 2021

Copyright (c) 2021 Jean de Dieu Baziki et al. This is an open access article distributed under the Creative Commons Attribution License, which permits unrestricted use, distribution, and reproduction in any medium, provided the original work is properly cited.

In the article titled "Development and Evaluation of an Immuno-Capture Enzyme-Linked Immunosorbent Assay to Quantify the Mycoplasma capricolum subsp. Capripneumoniae (Mccp) Protein in Contagious Caprine Pleuropneumonia (CCPP) Vaccine" [1], information was omitted in the Acknowledgments section. The corrected section appears as follows:

\section{Acknowledgments}

This work was mainly supported and funded by The Global Alliance for Livestock Veterinary Medicines (GALVmed) under the contract agreement AUP-R17A0079 "Development of an antigen quantification test for contagious caprine pleuropneumonia (CCPP) vaccine." The Pan African University Institute for Basic Sciences, Technology and Innovation
(PAUSTI) also supported a Ph.D. student working on the project.

\section{References}

[1] J. D. D. Baziki, B. S. Charles, N. Nwankpa et al., "Development and Evaluation of an Immuno-Capture Enzyme-Linked Immunosorbent Assay to Quantify the Mycoplasma capricolum subsp. Capripneumoniae (Mccp) Protein in Contagious Caprine Pleuropneumonia (CCPP) Vaccine," Veterinary Medicine International, vol. 2020, p. 10, 2020. 